\title{
Validation of an Analytical Method Based on High-Performance Liquid Chromatography for the Determination of Retinol in Chicken Liver
}

\author{
Rodrigo Albert Baracho Rüegg, Roberto Dimenstein \\ Federal University of Rio Grande do Norte, Natal, Brazil \\ Email: rodrigoruegg@gmail.com
}

How to cite this paper: Rüegg, R.A.B. and Dimenstein, R. (2020) Validation of an Analytical Method Based on HighPerformance Liquid Chromatography for the Determination of Retinol in Chicken Liver. Open Access Library Journal, 7: e6181. https://doi.org/10.4236/oalib.1106181

Received: February 20, 2020

Accepted: July 18, 2020

Published: July 21, 2020

Copyright $\odot 2020$ by author(s) and Open Access Library Inc.

This work is licensed under the Creative Commons Attribution International License (CC BY 4.0).

http://creativecommons.org/licenses/by/4.0/

\begin{abstract}
Retinol is an unsaturated fat-soluble isoprenoid alcohol. It is essential for the normal functioning of cells, human growth, and development, and it is found in animal sources in the form of palmitate ester. Chicken liver is an excellent source of retinol and is widely used in the diet of people in developing countries to combat Vitamin A deficiency. Several methods for the quantification of retinol in chicken liver have been reported in the literature. Most of them use more than one solvent for the determination and quantification of this micronutrient. A new method was developed based on a reverse phase system and using isocratic elution in a C18 column $(5 \mathrm{~mm}, 250 \times 4.6 \mathrm{~mm})$ coupled to a SPD-20A UV-VIS detector at a wavelength of $325 \mathrm{~nm}$ with a single mobile phase, methanol. The method is simple and inexpensive, allowing the rapid extraction, determination, and quantification of retinol in chicken liver samples, with an average retention time of $5.2 \mathrm{~min}$ at $23^{\circ} \mathrm{C}$, yielding good linearity results $\left(R^{2}=0.9999\right)$, standard stock and freeze-thaw process stabilities of 93.2\% and $97.5 \%$, respectively, precision with coefficients of variation below $15 \%$, and recovery coefficients ranging between $93 \%$ and $101.2 \%$.
\end{abstract}

\author{
Subject Areas \\ Analytical Chemistry \\ Keywords \\ HPLC, Validation, Retinol, Method, Methanol
}

\section{Introduction}

Vitamin A is a fat-soluble micronutrient that comprises a series of compounds 
displaying the biological activity of retinol (Figure 1), which exists either as preformed vitamin A (retinol, retinal, retinoic acid, and retinyl esters) or as pro-vitamin A (alpha-carotene, beta-carotene, and beta-cryptoxanthin) (YUYAMA et al., 2012) [1].

Retinol's function is associated with visual, reproductive, and immunological processes. It is also essential for cell differentiation and fetal development. Vitamin A deficiency (VAD) is still considered a global disease, particularly in emerging countries where its diagnosis is closely related to a low socioeconomic status. VAD affects the vision of the patient, initially with night blindness, and leading to possible xerophthalmia and keratomalacia symptoms. When untreated, these symptoms become irreversible, resulting in vision loss (BRASIL, 2009 [2]; GALLAGHER, 2010 [3]; SAUNDERS et al., 2009 [4]; YUYAMA et al., $2012[1])$.

Brazil presents a large number of cases of VAD in the Northeast region and in some regions of the Southeast, where the populations' diet is poor in both quality and quantity as a result of unsatisfactory living conditions. Micronutrient deficiencies are known as hidden hunger. Children, pregnant women, and nursing mothers present a higher risk of vitamin A deficiency (BRASIL, 2009) [2].

The main animal food sources of retinol are liver, fish oils, eggs, milk, and dairy products (ALMEIDA-MURADIAN; PENTEADO, 2003) [5]. Several studies have shown that liver, especially chicken liver, is an excellent source of vitamin A. Santos et al. (2009) evaluated the concentration of retinol in the liver of two different strains of chicken, Cobb and Ross, subjected to the same breeding process, which presented retinol values of $6678.0 \mu \mathrm{g} / 100 \mathrm{~g}$ and $8324.1 \mu \mathrm{g} / 100 \mathrm{~g}$, respectively. Rüegg and Dimenstein (2018) evaluated three batches of chicken liver from three brands sold in the supermarket, and found mean values of $9152.9 \mu \mathrm{g} / 100 \mathrm{~g}, 4673.1 \mu \mathrm{g} / 100 \mathrm{~g}$, and $5943.6 \mu \mathrm{g} / 100 \mathrm{~g}$. The Dietary Reference Intakes (DRI) is a commonly used reference for daily nutritional recommendations. The daily recommendation of vitamin A is $700 \mu \mathrm{g}$ for women over 14 years old and $900 \mu \mathrm{g}$ for men over 14 years old (INSTITUTE OF MEDICINE, 2001) [6].

Thus, in addition to its low cost, chicken liver has great potential to combat VAD (HOWELLS; LIVESEY, 1998 [7]; JAŚKIEWICZ; SAGAN; PUZIO, 2014 [8]; KANG; CHERIAN; SIM, 2006 [9]; MAJCHRZAK; FABIAN; ELMADFA, 2006 [10]; SCHINDLER; SCHOLZ; FELDHEIM, 1987 [11]; SURAI; KUKLENKO, 2000 [12]; TORRES et al., 1998 [13]).

Several studies have been conducted for the detection of retinol and retinyl

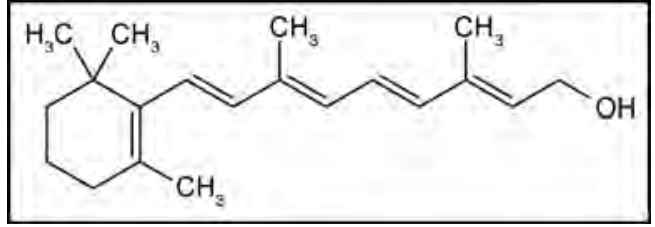

Figure 1. Chemical structure of retinol. 
esters in animal food sources using liquid chromatography in reverse phase and UV absorption detection (FURR; COOPER; OLSON, 1986 [14]; KANE; FOLIAS; NAPOLI, 2008 [15]; KARADAS et al., 2005 [16]; KIM; QUADRO, 2010 [17]; SATOMURA; KIMURA; ITOKAWA, 1992 [18]; SHINTAKU et al., 1998 [19]; TATUM; CHOW, 2005 [20]). However, most of these methods involve the use of more than one solvent under gradient conditions, which increases the cost of analysis. None of these tests used a $100 \%$ methanol mobile phase in an isocratic elution process.

Our study aimed to develop and validate a rapid and cheap method to extract and detect retinol in chicken liver using high-performance liquid chromatography (HPLC).

\section{Material and Methods}

\subsection{Reagents and Chemicals}

The all-trans retinol standard was acquired from Sigma-Aldrich, with $\geq 95 \%$ purity. The standard was stored according to the label instructions.

HPLC grade methanol was purchased from J. T. Baker. Other reagents including absolute ethanol (99.8\%) and ethanol (95\%) were acquired from Sigma-Aldrich (Rio de Janeiro/RJ), and hexane was obtained from Merck S.A. (Cotia/SP).

\subsection{Instrumentation}

The HPLC instrument consisted of an LC-20 AT pump coupled to an SPD-20A UV-VIS detector and a Rheodyne injection valve with a $20 \mu \mathrm{L}$ loop. A Hamilton syringe for manual injection with $100 \mu \mathrm{L}$ capacity and a computer with the LCsolution software for data acquisition and processing were used.

\subsection{Chromatographic Conditions}

The chromatographic separation was performed with a reversed phase column (Luna 5u C18 (2) 100A Phenomenex ${ }^{\oplus}, 250 \mathrm{~mm} \times 4.6 \mathrm{~mm}$ ) kept at a temperature of $23^{\circ} \mathrm{C}$. The UV-VIS detector was set to monitor the retinol absorbance at 325 nm.

The mobile phase used for the analysis of retinol in the samples was methanol $(100 \%)$ in an isocratic system with a flow of $1 \mathrm{~mL} / \mathrm{min}$.

Before use, the equipment was maintained under initial conditions with a flow rate of $1 \mathrm{~mL} / \mathrm{min}$ of methanol (100\%) for $30 \mathrm{~min}$.

\subsection{Stock and Working Solution Preparation}

The retinol solution standard was prepared by weighing $1.0 \mathrm{mg}$ of retinol (Sig$\mathrm{ma}$ ) in an Eppendorf tube, followed by dilution in $1.0 \mathrm{~mL}$ of absolute ethanol and stirring for $1 \mathrm{~min}$. Then, two further dilutions were carried out to reach an approximate concentration of $10 \mu \mathrm{g} / \mathrm{mL}$ (Figure 2). A spectrophotometer (U-2000 model from Hitachi) and quartz cuvettes were used for absorbance measurement. 


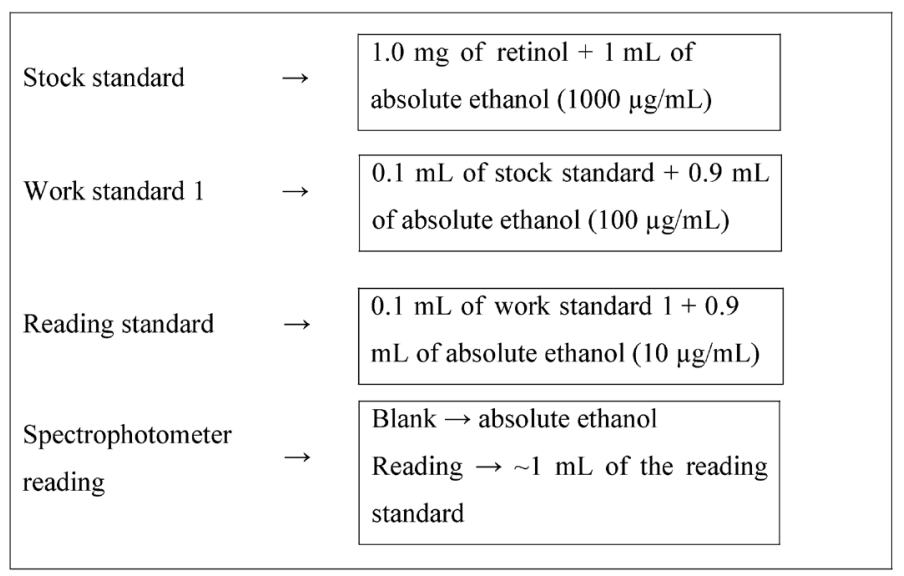

Figure 2. Methodology for the preparation of the reading standard.

The concentration of the standard was confirmed by the specific extinction coefficient of retinol in absolute ethanol $(\varepsilon 1 \%, 1 \mathrm{~cm}$ in ethanol $=1780$ at 325 nm) (MILNE; BOTNEN, 1986 [21]; SOLOMONS, 2012 [22]).

After confirmation of the actual concentration of the standard, a new dilution was performed from the reading standard in absolute ethanol (Figure 3), resulting in an approximate concentration of $1 \mu \mathrm{g} / \mathrm{mL}(1 \mathrm{ng} / 1 \mu \mathrm{L})$ for use in HPLC.

\subsection{Sample Preparation}

For the analysis of retinol in frozen chicken liver, $1 \mathrm{~kg}$ of fresh chicken liver was purchased at a supermarket in Natal, Brazil. The chicken liver was placed in a blender (Arno model) together with one liter of saline solution $(\mathrm{NaCl}, 0.9 \%)$, forming a homogenate at $50 \%$. Falcon tubes were filled with $1 \mathrm{~g}$ of the homogenate and stored on a freezer at $-18^{\circ} \mathrm{C}$ for $0,1,15$, and 30 days.

\subsubsection{Extraction of Retinol from Chicken Liver}

The extraction of retinol from chicken liver was performed according to Hosotani and Kitagawa (2003) [23] and described below.

One milliliter of ethanol (95\%) was added to each Falcon tube containing $1 \mathrm{~g}$ of the homogenate in order to precipitate the proteins present in the sample.

Before lipid extraction, saponification was achieved by adding $1 \mathrm{~mL}$ of potassium hydroxide $(\mathrm{KOH}, 50 \%)$ and the samples were placed in a water bath at $60^{\circ} \mathrm{C}$ for 1 hour under stirring in order to hydrolyze the retinyl esters present in the samples.

For lipid extraction, the samples were washed with $2 \mathrm{~mL}$ of hexane and stirred for $1 \mathrm{~min}$, and then were left standing for $5 \mathrm{~min}$. The supernatant was then placed in a new tube, and this process was repeated twice, resulting in a final volume of approximately $6 \mathrm{~mL}$ of hexane. An aliquot of $250 \mu \mathrm{L}$ of hexane was taken, placed in another $5 \mathrm{~mL}$-polypropylene tube and evaporated to dryness in a water bath at $37^{\circ} \mathrm{C}$ under nitrogen atmosphere (White Martins ${ }^{\circledR}$ ). Aliquot was due to two reasons: evaporation time of hexane and the aliquot prevents HPLC 


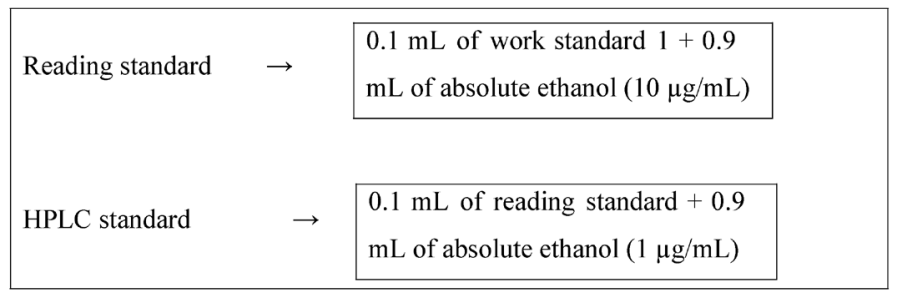

Figure 3. Methodology for the preparation of the HPLC standard.

column obstruction due to the high content of retinol in chicken liver samples. The samples were then stored at $-18^{\circ} \mathrm{C}$ under nitrogen atmosphere, and protected from light. Before HPLC processing, the samples were redissolved in $1 \mathrm{~mL}$ of absolute ethanol, and $20 \mu \mathrm{L}$ of the samples was then used for HPLC. The measurements were carried out in duplicate injections and the average was calculated over the two obtained areas.

\subsubsection{Retinol Identification}

The identification and quantification of retinol in the samples was evaluated by means of comparison of the retention time of the all-trans retinol standard and the peak in the sample analyzed under the same conditions comparison of the areas in the chromatographic profile with the areas of the pattern.

\subsubsection{Validation}

The validation of the method was performed according to the current FDA guidelines, i.e., the Guidelines on Bioanalytical Method Validation (FOOD AND DRUG ADMINISTRATION, 2013 [24]).

\subsubsection{Linearity}

The linearity of the method is the instrumental response of the linear calibration relationship (obtained area) with the concentration of the standard, being satisfactory when the correlation coefficient is close to 1 (BRITO et al., 2003) [25].

Six different dilutions of the retinol standard were used for application in HPLC. Next, the plot of the linear equation was built from their respective areas, and a straight line equation was obtained through linear regression (peak area versus concentration of the standard).

\subsubsection{Stability}

The stability of the retinol stock standard was determined in triplicate with aliquots that were stored in a freezer at $-18^{\circ} \mathrm{C}$ and evaluated in cycles of 1,15 , and 30 days.

In order to evaluate the stability of retinol in the chicken liver samples, the latter were stored in a freezer at $-18^{\circ} \mathrm{C}$ and assessed in thawing cycles at room temperature $\left(24^{\circ} \mathrm{C}\right)$ for 8 hours after 1,15 , and 30 days.

\subsubsection{Precision}

The precision of the method was analyzed through a repeatability test. For the 
assessment of the intra-precision, five replicates at three different retinol concentrations in the range of $2.0-5.0 \mu \mathrm{g} / \mathrm{mL}$ were prepared and analyzed in the same day.

For the assessment of the inter-precision, the intra-precision measurement was repeated for five consecutive days. The coefficient of variation (CV) was calculated from the standard deviation of the mean and expressed as a percentage.

\subsubsection{Accuracy}

The accuracy of the method was evaluated by a recovery test. Known amounts of the retinol standard solution were added in triplicate at three different concentrations $(0.00436,0.008072$, and $0.012108 \mathrm{mg} / \mathrm{mL})$ to the chicken liver samples. These concentrations were a practical application in HPLC and it was set to identify peaks at this concentration. These samples were subjected to the same retinol extraction method and analyzed by HPLC. The recovery was calculated by the ratio of the sample peak area and the standard solution peak area added 100 times, and expressed as a percentage.

\subsubsection{Limit of Detection (LOD) and Limit of Quantification (LOQ)}

In order to determine the LOD and LOQ, several injections were performed at decreasing concentrations. The lowest detectable, but not quantifiable concentration is the LOD. This in turn was detected by a visual method using a matrix after addition of known concentrations so that the analytical signal was distinguished from the noise for the lowest detectable concentration (RIBANI et al., 2004) [26].

The lowest concentration that can be quantified with acceptable precision and accuracy is the LOQ. This was detected when the analytical signal was identified in the lowest equivalent dilution (RIBANI et al., 2004) [26].

\section{Results and Discussion}

The use of HPLC has become a common method for the quantification of vitamins and minerals because of its sensitivity and accuracy. The development of methods based on HPLC presents many advantages such as speed, resolution power, the reduction of the amount of sample and solvent used, and low cost; thus encompassing several environmental benefits (CHEN; KORD, 2009) [27].

\subsection{Linearity}

Six different dilutions of the retinol standard $(3.37 \mathrm{ng} / 20 \mu \mathrm{L}, 6.75 \mathrm{ng} / 20 \mu \mathrm{L}, 13.49$ $\mathrm{ng} / 20 \mu \mathrm{L}, 26.98 \mathrm{ng} / 20 \mu \mathrm{L}, 53.96 \mathrm{ng} / 20 \mu \mathrm{L}$, and $107.92 \mathrm{ng} / 20 \mu \mathrm{L}$ ) were applied for HPLC. The linear plot was built from their respective areas $(26.426,55.687$, $119.135,238.471,498.955$, and 989.117). The equation of the straight line obtained by linear regression, with $R^{2}=0.9999$, is shown in Figure 4, illustrating the linear relationship of peak area versus concentration of the standard. 


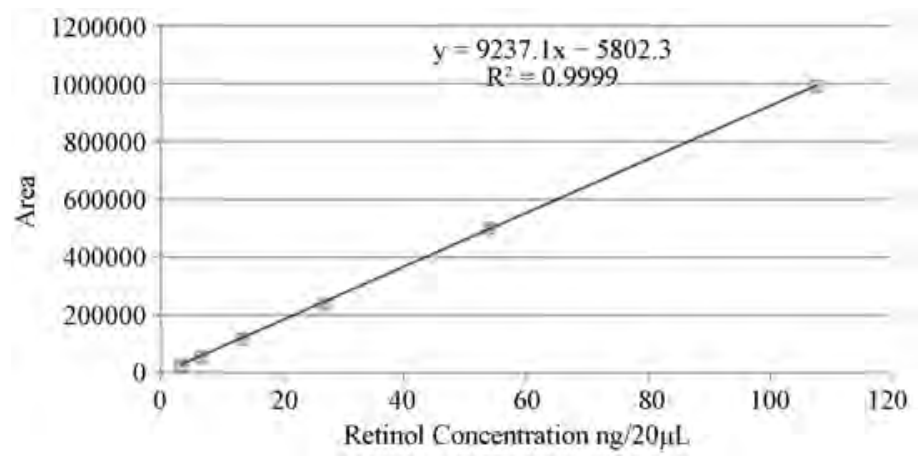

Figure 4. Calibration curve and linear equation obtained by analyzing different concentrations of the retinol standard with HPLC.

\subsection{Stability}

The retinol stock solution standard was stable for at least 30 days. The area of the standard peak was compared to the value of the area of the peak in the chromatogram measured on a particular day, yielding a stable average value of 93.2\%.

The stability of retinol in the freeze-thawing process of chicken liver samples was determined to be at least 30 days, yielding a stable average value of $97.5 \%$.

\subsection{Precision}

The intra- and inter-precision data for the method are shown in Table 1. Values below 15\% are considered acceptable (FDA - FOOD AND DRUG ADMINISTRATION, 2013) [24]. As it can be seen, the precision values of the present method were all found to be below $15 \%$.

\subsection{Accuracy}

The accuracy of the method was assessed through the recovery of the standard added to chicken liver samples at three different concentrations. The results are summarized in Table 2.

The average recovery ranged between $93 \%$ and $101.2 \%$, while the coefficient of variation for the recovery ranged between 0.36 and 0.98 . The results indicate that the method is precise for the determination of retinol in chicken liver.

\subsection{LOD and LOQ}

The limit of detection and limit of quantification are shown in Table 3. The values of sensitivity are satisfactory for the precise determination of retinol in chicken liver.

\subsection{Applicability of the Method}

The applicability of the method was verified using liver samples subjected to retinol extraction. A stock standard solution of retinol (with a concentration of $1217 \mathrm{ng} / \mathrm{mL}$ ) was added to one of the samples (what is called 'spiking') to assess 
Table 1. Intra- and inter-precision of the method for the determination of retinol (CV: coefficient of variation).

\begin{tabular}{ccccc}
\hline Analyte & \multicolumn{2}{c}{ Intra-precision } & \multicolumn{2}{c}{ Inter-precision } \\
\hline & $\mu \mathrm{g} / \mathrm{mL}$ & $\mathrm{CV}(\%)$ & $\mu \mathrm{g} / \mathrm{mL}$ & $\mathrm{CV}(\%)$ \\
\cline { 2 - 5 } Retinol & 2.0 & 3.0 & 2.0 & 9.7 \\
& 4.0 & 2.3 & 4.0 & 14.2 \\
& 5.0 & 7.8 & 5.0 & 12.2 \\
\hline
\end{tabular}

Table 2. Recovery values of the method for the determination of retinol.

\begin{tabular}{ccc}
\hline Concentration of the standard added $(\mathrm{ng} / \mathrm{mL})$ & Recovery $(\%)$ & CV $(\%)$ \\
4036 & 93 & 0.98 \\
8072 & 98.5 & 0.36 \\
12108 & 101.2 & 0.91 \\
\hline
\end{tabular}

Table 3. Limit of detection (LOD) and limit of quantification (LOQ) of retinol.

\begin{tabular}{cc}
\hline Parameter & Concentration $(\mathrm{ng} / \mathrm{mL})$ \\
\hline LOD & 9.1 \\
LOQ & 18.26 \\
\hline
\end{tabular}

the suitability of the method and peak separation. Figure 5 and Figure 6 show the resulting chromatograms, where the successful separation of the analytes can be observed.

Other experimental applicability was made. Samples from organic, free-range and three brands of chicken liver, chilled, within the expiry date, and traded in supermarkets in the greater area of Natal, Brazil, were evaluated by using this method. This study found statistically different values among the means of the three different chicken liver (RÜEGG; DIMENSTEIN, 2018) [28].

Rüegg and Dimenstein (2018) also used this method to evaluate retinol from chicken liver in different cooking and defrost methods. The authors found a statistically decreased when chicken liver was submitted for $1 \mathrm{~min}$ in a microwave in defrost function.

\subsection{Comparison of the Method}

The present study corroborates with other methodologies using methods similar to this one developed with liver of chicken.

Yokota and Oshio (2018) [29] developed a methodology for extraction, identification and quantification of retinol in mice's livers, also using $100 \%$ methanol in the mobile phase, obtaining a mean retention time of 3.2 minutes using a Mightysil RP-18 GP column. A similar result was observed with de Aquino et al. (2006) [30], which had a mean retention time of 4.3 minutes, using LC Shim-pack CLC-ODS (M) $4.6 \mathrm{~mm} \times 25 \mathrm{~cm}$ column and the same mobile phase but in bovine liver. 


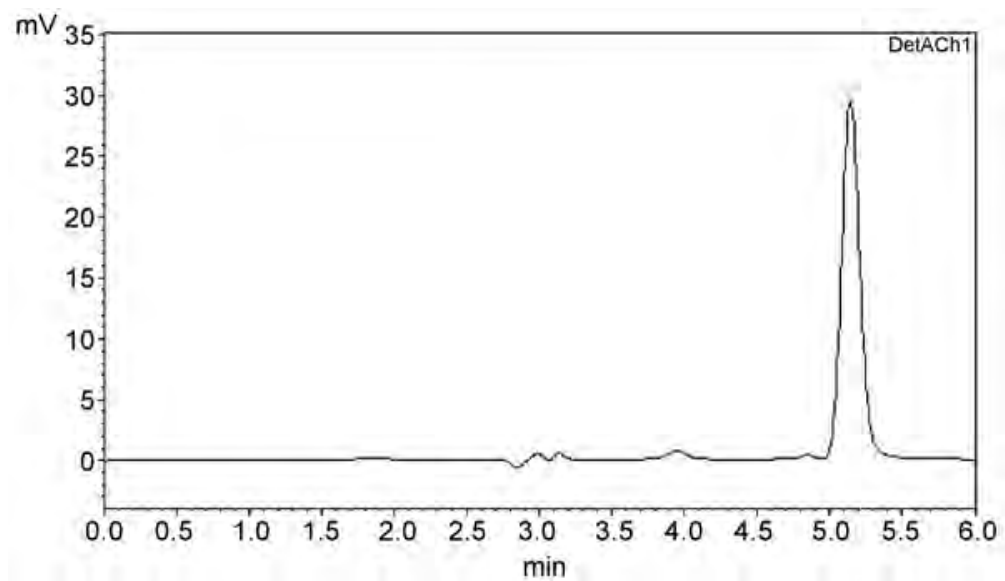

(a)

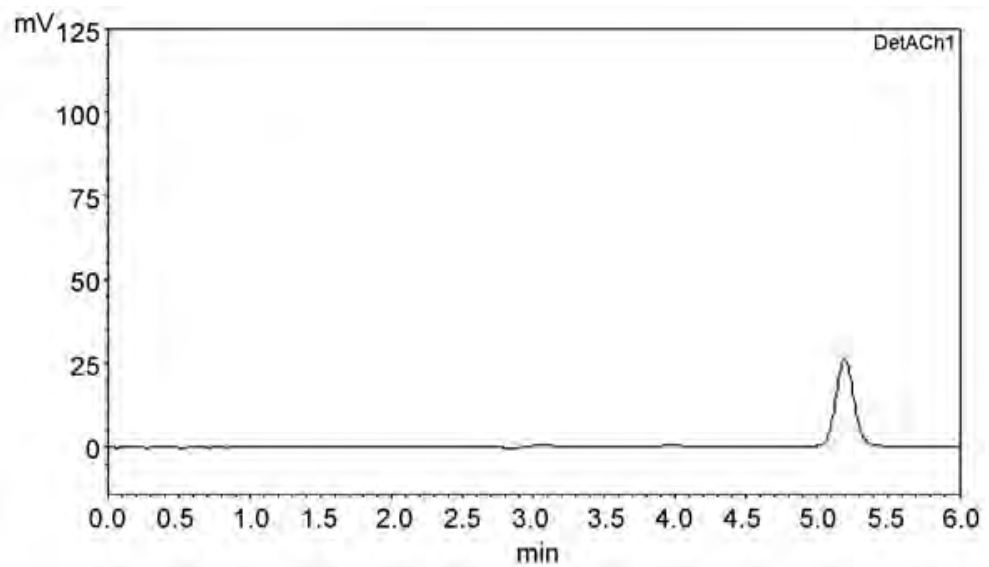

(b)

Figure 5. HPLC elution profile of retinol. (a) All-trans retinol chromatogram of a $24.35 \mathrm{ng} / 20 \mu \mathrm{L}$ sample. (b) Chromatogram of a chicken liver sample subjected to retinol extraction.

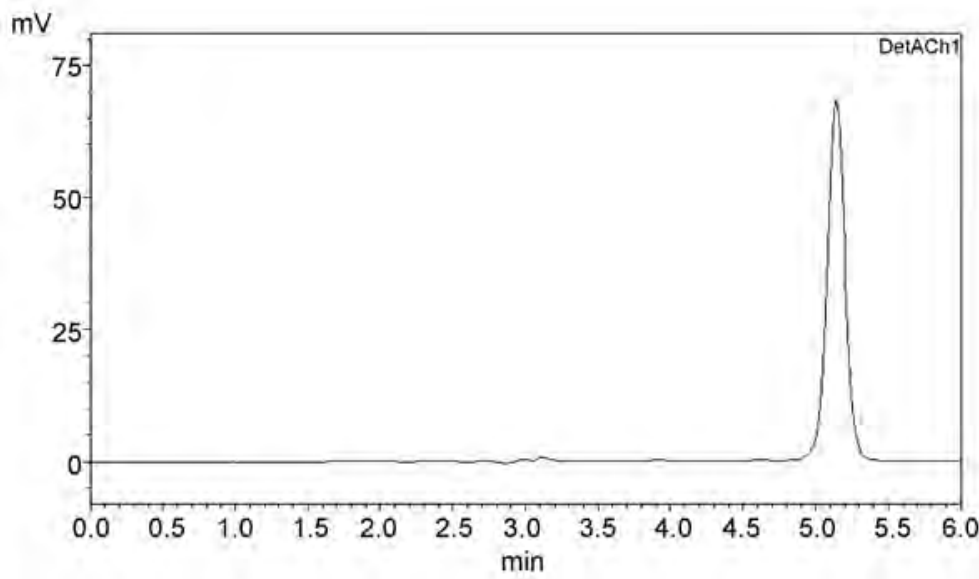

Figure 6. Chromatogram of a spiked sample of chicken liver with an all-trans retinol standard $(1217 \mathrm{ng} / \mathrm{mL})$.

Other methodologies using a gradient elution are also seen in the literature, for example combinations of methanol and acetonitrile $(15: 85 \mathrm{v} / \mathrm{v})$ in the identi- 
fication and quantification of retinol in pig liver, obtaining an average retention time of 4 minutes (MAJCHRZAK; FABIAN; ELMADFA, 2006) [10].

A mean retention time of about 3 minutes was observed in the study of Howells and Livesey (1998) [7] with pigs, cattle and chickens livers and using acetonitrile, $\mathrm{n}$-butanol and acetic acid $(60: 40: 0.1 \mathrm{v} / \mathrm{v} / \mathrm{v})$ as the mobile phase, but in a flow of $1.5 \mathrm{~mL} / \mathrm{min}$ and a C18 column, different from the present study that used a flow of $1.0 \mathrm{~mL} / \mathrm{min}$ and a Luna $5 \mathrm{u}$ C18 (2) $100 \mathrm{~A}$ Phenomenex ${ }^{\oplus}$ column.

\section{Conclusions}

Although the retention times changed depending on column batch, flow speed, and consistency of the mobile phase, it was possible to identify and quantify the amount of retinol in chicken liver samples using reverse phase HPLC coupled with UV-VIS detection of its absorbance at $325 \mathrm{~nm}$ using an isocratic method with a single mobile phase (methanol 100\%), resulting in an average retention time of 5.2 minutes.

The analytical method developed in this study is consistent with its function and with the current legislation policy, being economical, quick, easy, and suitable for its proposal.

\section{Acknowledgements}

The author thanks FAPERN, CAPES and PPG/UFRN for financial support.

\section{Conflicts of Interest}

The author declares no conflicts of interest regarding the publication of this paper.

\section{References}

[1] Yuyama, L.K.O., et al. (2012) Vitamina A (Retinol) e Carotenóides. In: Biodisponibilidade de nutrients, 4th Edition, Manole, Barueri/SP, 297-342.

[2] Brasil; Ministério Da Saúde (2009) Pesquisa Nacional de Demografia e Saúde da Criança e da Mulher. PNDS 2006: Dimensões do Processo Reprodutivo e da Saúde da Criança. Centro Brasileiro de Análise e Planejamento. Série G. Estatística e Informação em Saúde. $\underline{\text { http://bvsms.saude.gov.br/bvs/publicacoes/pnds_crianca_mulher.pdf }}$

[3] Gallagher, M.L. (2010) Os Nutrientes e Seu Metabolismo. In: Gallagher, M., Ed., Krause: Alimentos, nutrição e dietoterapia, Elsevier, Rio de Janeiro, 68.

[4] Saunders, C., et al. (2009) Boletim carências nutricionais: Deficiência de vitamina A DVA. No. 2, p. 8.

[5] Almeida-Muradian, L.B. and Penteado, M.V.C. (2003) Vitamina A. In: Vitaminas. Aspectos Nutricionais, bioquímicos, clínicos e analíticos, Manole, Barueri/SP, 55-74.

[6] Institute of Medicine (IOM) (2001) Dietary Reference Intakes for Vitamin A, Vitamin K, Arsenic, Boron, Chromium, Copper, Iodine, Iron, Manganese, Molybdenum, Nickel, Silicon, Vanadium, and Zinc: A Report of the Panel on Micronutrients. Nutrition Reviews, 55, 319-326. 
[7] Howells, L.C. and Livesey, C.T. (1998) A Survey of Vitamin A Concentrations in the Liver of Food-Producing Animals. Food Additives and Contaminants, 15, 10-18. https://doi.org/10.1080/02652039809374595

[8] Jaśkiewicz, T., Sagan, A. and Puzio, I. (2014) Effect of the Camelina sativa Oil on the Performance, Essential Fatty Acid Level in Tissues and Fat-Soluble Vitamins Content in the Livers of Broiler Chickens. Livestock Science, 165, 74-79. https://doi.org/10.1016/j.livsci.2014.04.003

[9] Kang, K.R., Cherian, G. and Sim, J.S. (2006) Tocopherols, Retinol and Carotenes in Chicken Egg and Tissues as Influenced by Dietary Palm Oil. Journal of Food Science, 63, 592-596. https://doi.org/10.1111/j.1365-2621.1998.tb15792.x

[10] Majchrzak, D., Fabian, E. and Elmadfa, I. (2006) Vitamin A Content (Retinol and Retinyl Esters) in Livers of Different Animals. Food Chemistry, 98, 704-710. https://doi.org/10.1016/j.foodchem.2005.06.035

[11] Schindler, R., Scholz, M. and Feldheim, W. (1987) Quantitative Determination of Vitamin A in Liver and Liverwurst Using High Pressure Liquid Chromatography (HPLC). Zeitschrift für Lebensmittel-Untersuchung und-Forschung, 185, 208-212. https://doi.org/10.1007/BF01042048

[12] Surai, P.F. and Kuklenko, T.V. (2000) Effects of Vitamin A on the Antioxidant Systems of the Growing Chicken. Asian-Australasian Journal of Animal Sciences, 13, 1290-1295. https://doi.org/10.5713/ajas.2000.1290

[13] Torres, E.A.F.S., et al. (1998) Teor em vitamina A, de alguns alimentos distribuidos na cidade de São Paulo. Higiene Alimentar, 12, 58-61.

[14] Furr, H.C., Cooper, D.A. and Olson, J.A. (1986) Separation of Retinyl Esters by Non-Aqueous Reversed-Phase High-Performance Liquid Chromatography. Journal of Chromatography, 378, 45-53. https://doi.org/10.1016/S0378-4347(00)80698-2

[15] Kane, M.A., Folias, A.E. and Napoli, J.L. (2008) HPLC/UV Quantitation of Retinal, Retinol, and Retinyl Esters in Serum and Tissues. Analytical Biochemistry, 378, 71-79. https://doi.org/10.1016/j.ab.2008.03.038

[16] Karadas, F., et al. (2005) Effects of Maternal Dietary Supplementation with Three Sources of Carotenoids on the Retinyl Esters of Egg Yolk and Developing Quail Liver. Comparative Biochemistry and Physiology-A Molecular and Integrative Physiology, 140, 430-435. https://doi.org/10.1016/j.cbpb.2005.02.005

[17] Kim, Y.-K. and Quadro, L. (2010) Reverse-Phase High-Performance Liquid Chromatography (HPLC) Analysis of Retinol and Retinyl Esters in Mouse Serum and Tissues. Methods in Molecular Biology, 652, 263-275. https://doi.org/10.1007/978-1-60327-325-1_15

[18] Satomura, Y., Kimura, M. and Itokawa, Y. (1992) Short Communication Simultaneous Determination of Allantoin and Oxypurines in Biological Fluids by HighPerformance Liquid Chromatography. Journal of Chromatograpy, 625, 372-376. https://doi.org/10.1016/0021-9673(92)85224-H

[19] Shintaku, T., et al. (1998) Detection of Retinyl Palmitate and Retinol in the Liver of Mice Injected with Excessive Amounts of Retinyl Acetate. The Journal of Veterinary Medical Sciencel The Japanese Society of Veterinary Science, 60, 471-477. https://doi.org/10.1292/jvms.60.471

[20] Tatum, V. and Chow, C.K. (2005) Rapid Measurement of Retinol, Retinal, 13-Cis-Retinoic Acid and All-Trans-Retinoic Acid by High Performance Liquid Chromatography. Journal of Food and Drug Analysis, 13, 256-259.

[21] Milne, D.B. and Botnen, J. (1986) Retinol, Alpha-Tocopherol, Lycopene, and Alpha- 
and Beta-Carotene Simultaneously Determined in Plasma by Isocratic Liquid Chromatography. Clinical Chemistry, 32, 874-876.

https://doi.org/10.1093/clinchem/32.5.874

[22] Solomons, N.W. (2012) Vitamin A. In: Present Knowledge in Nutrition, 10th Edition, International Life Sciences Institute (ILSI), Washington DC, 149-185.

https://doi.org/10.1002/9781119946045.ch11

[23] Hosotani, K. and Kitagawa, M. (2003) Improved Simultaneous Determination Method of Beta-Carotene and Retinol with Saponification in Human Serum and Rat Liver. Journal of Chromatography. B, Analytical Technologies in the Biomedical and Life Sciences, 791, 305-313. https://doi.org/10.1016/S1570-0232(03)00233-2

[24] FDA Food and Drug Administration (2013) Guidance for Industry: Bioanalytical Method Validation. U.S. Department of Health and Human Services, Washington DC, 22.

[25] Brito, N.M., et al. (2003) Validação De Métodos Analíticos: Estratégia E Discussão. Revista de Ecotoxicologia e Meio Ambiente, 13, 129-146. https://doi.org/10.5380/pes.v13i0.3173

[26] Ribani, M., et al. (2004) Validação em métodos cromatográficos e eletroforéticos. Quimica Nova, 27, 771-780. https://doi.org/10.1590/S0100-40422004000500017

[27] Chen, S. and Kord, A. (2009) Theoretical and Experimental Comparison of Mobile Phase Consumption between Ultra-High-Performance Liquid Chromatography and High Performance Liquid Chromatography. Journal of Chromatography A, 1216, 6204-6209. https://doi.org/10.1016/j.chroma.2009.06.084

[28] Rüegg, R.A.B. and Dimenstein, R. (2018) Effects of Cooking and Defrost Methods on Retinol Concentration of Chicken Liver. Journal of Food and Nutrition Research, 6, 146-151.

[29] Yokota, S. and Oshio, S. (2018) A Simple and Robust Quantitative Analysis of Retinol and Retinyl Palmitate Using a Liquid Chromatographic Isocratic Method. Journal of Food and Drug Analysis, 26, 504-511. https://doi.org/10.1016/j.jfda.2017.07.002

[30] De Aquino, R.C.P., et al. (2006) Analysis of Retinol Concentrations in Bovine Liver and Its Habitual Consumption by Pregnant Women. Annals of Nutrition and Metabolism, 50, 325-329. https://doi.org/10.1159/000094295 